\title{
International importance of Extremadura, Spain, for overwintering migratory dabbling ducks: a role for reservoirs
}

\author{
JUAN G. NAVEDO, JOSÉ A. MASERO, JUAN M. SÁNCHEZ-GUZMÁN, \\ JOSÉ M. ABAD-GÓMEZ, JORGE S. GUTIÉRREZ, ESTHER G. SANSÓN, \\ AUXILIADORA VILLEGAS, EMILIO COSTILLO, CASIMIRO CORBACHO \\ and RICARDO MORÁN
}

\section{Summary}

Many migratory waterbird populations are in decline and loss of natural wetlands is one of the main causes. However, some species may respond positively to artificial wetland recreation. In Extremadura (south-west Europe), several large reservoirs were created for irrigation since the 1960s and some comparatively small reservoirs were built from the late 1990s onwards close to rice fields. Here we analyse the abundance of wintering dabbling ducks (Anas spp.) in Extremadura before (1991-1994) and after (2007-2010) the creation of these new reservoirs in order to address the current importance of the area for this guild within the East Atlantic Flyway (EAF). A mean of 25,277 dabbling ducks wintered in the study area during 1991-1994, increasing to 46,163 individuals during 2007-2010. After controlling for environmental variables, Northern Pintail Anas acuta, Common Teal A. crecca and Northern Shoveler A. clypeata experienced significant increases in the area between both periods, and only Eurasian Wigeon $A$. penelope suffered a significant decrease. Mallard A. platyrhynchos and Gadwall A. strepera populations did not show any significant trend. The large older reservoirs experienced overall population decreases between the two periods, with four new reservoirs holding more than 35,000 wintering dabbling ducks. Our results reflect an overall improvement in habitat conditions, driven by the creation of reservoirs near to rice fields that could have resulted in a partial redistribution of wintering dabbling ducks in the EAF. The area emerges as one of the most important wintering sites for dabbling ducks in southern Europe, regularly exceeding two of the Ramsar Convention criteria for the conservation of several populations. The protection of these new reservoirs by legal mechanisms would guarantee the existence of a large functional wetland area, which could also mitigate the loss of natural wetlands for populations using the EAF.

\section{Introduction}

The most recent review of the population status of migratory waterbirds confirms that many of them are in decline (Delany and Scott 2006). Several factors may be impacting negatively on these populations, but loss and/or alteration of natural wetlands are probably the main cause (Morrison et al. 2001, Green et al. 2002, Zwarts et al. 2008). A global overview shows that over half of large river systems (172 out of 292) are affected by dams, including the eight most biogeographically diverse (Nilsson et al. 2005). Despite of the overall biodiversity loss (Nilsson et al. 2005) and the modification of ecological function (Dugan 1990), some waterbird species can respond positively to dam construction (i.e. creation of artificial wetlands) (Pandey 1993, Okes et al. 2008). In this context, there is increasing evidence that several anthropogenic wetlands could reduce the impact of natural 
wetland loss for migratory waterbirds (Elphick 2000, Masero 2003, Kloskowski et al. 2009, Yasué and Dearden 2009, Toral and Figuerola 2010).

Outside tidal areas, most wintering dabbling ducks (genus Anas) are known to use roosting sites during the day and separate foraging sites at night, thus showing commuting behaviour (Weller 1988, McNeil et al. 1992, Cox and Afton 1996, Guillemain et al. 2002, Kloskowski et al. 2009). Diurnal roosts and nocturnal feeding areas form a functional and geographically linked system for wintering ducks (Tamisier 1985). Diurnal roosts should be disturbance-free (Fox and Madsen 1997) and dabbling ducks select them on the basis of low predation risk (hunting pressure), as well as low commuting cost (distance to foraging grounds) (Brochet et al. 2009). Within the Palearctic-African migratory system (Moureau 1972), southern Europe represents the limit of the winter distribution of several dabbling duck populations (Scott and Rose 1996, Kear 2005). Among these, only Northern Pintail Anas acuta and to a lesser extent Northern Shoveler Anas clypeata, winter in important numbers at Sahelian wetlands (Scott and Rose 1996, Zwarts et al. 2008); the exception is Garganey Anas querquedula, with nearly the whole population wintering in these African wetlands (Zwarts et al. 2008). During hard winters there is an increase in the number of waterbirds that winter in the southern part of the distribution range, due to a reduction in the availability of food resources and increased living costs derived from cold spells (e.g. Camphuysen et al. 1996, Hulscher et al. 1996) and dabbling ducks are very susceptible to these periods (Ridgill and Fox 1990, Guillemain et al. 2005). Therefore, temperatures registered in northern areas could affect the abundance of different dabbling duck species wintering further south.

In the East Atlantic Flyway (henceforth EAF), the Doñana marshes in the Guadalquivir basin (south-west Spain), have been considered one of the most important wintering areas for dabbling duck populations (Scott and Rose 1996), and the status of this area has recently been updated (Rendón et al. 2008). In this area, anthropogenic wetlands (extensive fishponds and rice fields) created in the early 1990s provided suitable complementary habitats for duck species, their role being particularly important during years of drought (Kloskowski et al. 2009). Ducks were concentrated in these artificial wetlands during summer and dry winters, but dispersed to natural marshes as more of these became flooded (Kloskowsi et al. 2009). Considering the rapid turnover in wintering populations of some duck species (Pradel et al. 1997, Guillemain et al. 2010), changes in numbers throughout a given winter should reflect influxes/departures of birds using other nearby areas (Kloskowski et al. 2009).

The Guadiana basin in Extremadura, south-west Spain, is located less than $300 \mathrm{~km}$ north of Doñana. From the early 1960 s to early 1990s, large reservoirs (1,500-15,000 ha) were constructed here to irrigate new agricultural areas, such as rice fields created at the same time (today 30,000 ha; Sánchez-Guzmán et al. 2007). In 1996, a large reservoir in Extremadura named Orellana was identified as a key site for the conservation of Anatidae populations in Africa and Western Eurasia due to wintering concentrations of Mallard Anas platyrhynchos and Gadwall Anas strepera (Scott and Rose 1996). In the late 1990s, other comparatively small reservoirs $(<1,500$ ha) were built in this part of the Guadiana basin, close to the rice growing area, to increase the area under irrigation. Although Orellana is listed among the main sites for waterbirds in Spain (Martí and Del Moral 2003), the importance of Extremadura for overwintering dabbling ducks remains largely unstudied.

We analysed the population sizes of dabbling ducks overwintering in the main anthropogenic wetlands in the middle Guadiana basin before and after the construction of small new reservoirs near the rice fields. The aims of this study were to (I) estimate the population sizes of dabbling ducks overwintering in this artificial area and (2) evaluate the role of these comparatively small reservoirs for overwintering dabbling ducks in Extremadura.

\section{Methods}

\section{Study area}

The study area is located in the middle basin of the river Guadiana in Extremadura $\left(38^{\circ} \mathrm{N}, 6^{\circ} \mathrm{W}\right.$; Figure 1 ). The climate is typically Mediterranean, with mild winter temperatures and autumn 


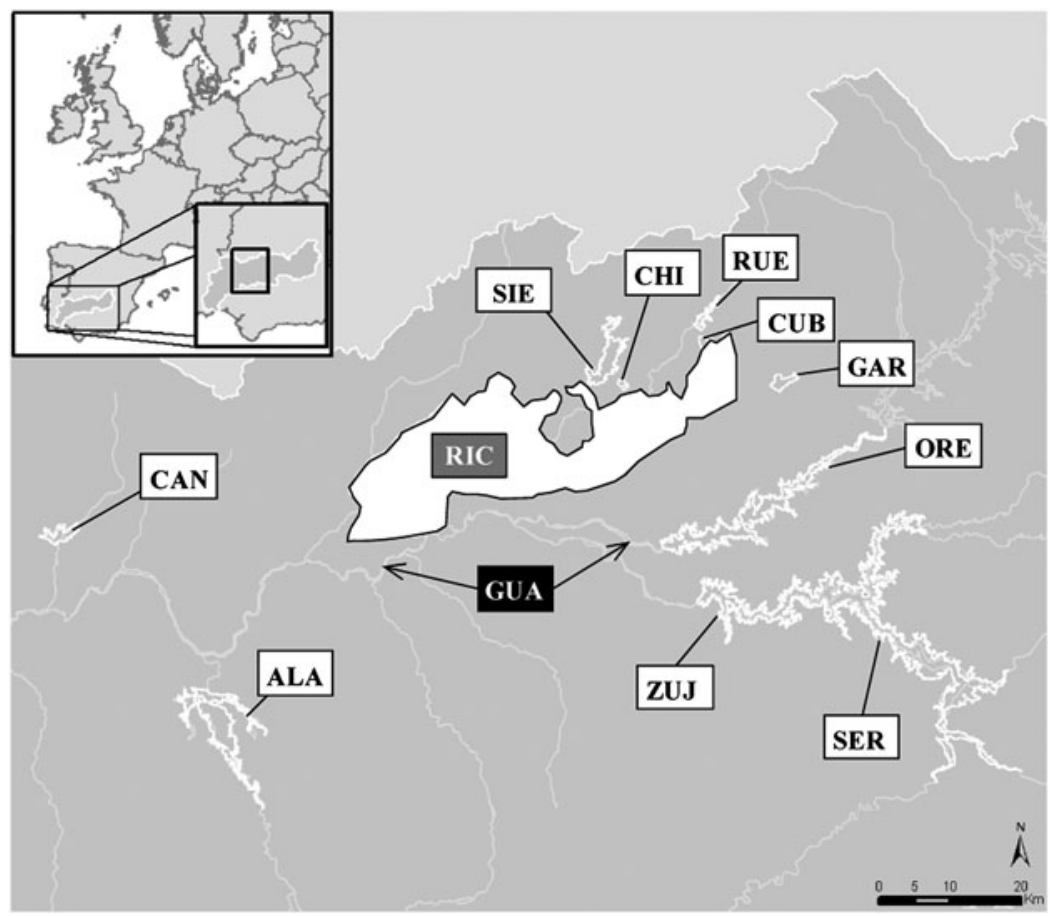

Figure 1. Map of the middle Guadiana basin (SW Spain) indicating the location of the reservoirs analysed within the study area, as well as the surrounding rice fields and the Guadiana river. ALA = Alange; $\mathrm{CAN}=$ Canchales; $\mathrm{ORE}=$ Orellana; $\mathrm{SER}=$ Serena; $\mathrm{ZUJ}=$ Zújar; $\mathrm{CHI}=$ Casas de Hitos; $\mathrm{CUB}=$ Cubilar; $\mathrm{GAR}=$ Gargáligas; $\mathrm{RUE}=$ Ruecas; $\mathrm{SIE}=$ Sierra Brava; $\mathrm{RIC}=$ Rice fields; $\mathrm{GUA}=$ Guadiana river.

rainfall (Felicísimo et al. 2001). Many reservoirs have been constructed to regulate the hydrological system to prevent flooding and for irrigation purposes (García 1994) of historically extensive dry lands (Sánchez et al. 1993), especially for rice fields in the 1960s and 1970s. The geology is predominantly siliceous and the area is characterised by low and gradual relief (206-426 m asl) (Zamora 1987). Due to autumn rainfall, the area of shallow water greatly expands from the second part of November. These areas usually remain flooded throughout the winter until the rice production cycle begins in spring (more details in Sánchez-Guzmán et al. 2007).

Since the early 1960s, three large reservoirs (Orellana, Zújar and Serena) located in the region of the upper floodplain have been available for waterbirds (Table 1; Figure 1). Orellana was listed as a Ramsar site in 1996 because of its importance for overwintering waterbird populations (criterion 5: regularly support more than 20,000 waterbirds), including ducks and geese (Scott and Rose 1996). Martí and Del Moral (2003) summarised Anatidae populations in Orellana for the period 1991-2001, giving a mean of 4,637 Mallard (range: 969-8,896), 1,833 Common Teal Anas crecca (range: 396-4,150), and 1,505 Eurasian Wigeon A. penelope (range: 206-2,953), among others. During this time there was another artificial wetland available for waterbird populations within this area, named Casas de Hitos, an irrigation pool of 6.2 ha completely surrounded by rice fields (Figure 1). Two other large reservoirs in the area, Cíjara and Puerto Peña, were not used by large numbers of dabbling ducks (authors' unpubl. data) probably because of their unsuitable habitat (a narrow water body completely surrounded by large cliffs and/or forests). Two other large reservoirs located $70-80 \mathrm{~km}$ away from the rice fields have been available for waterbirds 
Table 1. Year of dam inundation to $90 \%$ level (first operative year) and maximum area of each reservoir within the study area.

\begin{tabular}{lllr}
\hline CODE & Reservoir & Operative year & Max surface (ha) \\
\hline ORE & Orellana & 1961 & 5,084 \\
ZUJ & Zújar & 1964 & 1,449 \\
CHI & Casas de Hitos & 1971 & 6 \\
SER & Serena & 1989 & 13,949 \\
CAN & Canchales & 1991 & 970 \\
ALA & Alange & 1991 & 5,144 \\
SIE & Sierra Brava & 1994 & 1,650 \\
RUE & Ruecas & 1996 & 397 \\
GAR & Gargáligas & 1999 & 372 \\
CUB & Cubilar & 1999 & 142 \\
\hline
\end{tabular}

since the early 1990s: Alange and Canchales (Table 1; Figure 1). Finally, another four reservoirs of smaller size (Sierra Brava, Gargáligas, Ruecas, and Cubilar) were created between 1994 and 1999 near to the rice fields to improve irrigation (Table 1; Figure 1). These new reservoirs increased the permanently inundated area available for waterbirds by 2,561 ha (Table 1 ), representing approximately $8 \%$ of the total permanently inundated area.

\section{Duck counts}

To estimate the number of ducks, we performed monthly surveys of the whole study area during the wintering period (November-February; Rendón et al. 2008). Dabbling ducks wintering in the study area roost in the reservoirs during daylight, and leave en masse at dusk to forage on crops in surrounding fields. This behaviour is common in other wetlands within the EAF (Brochet et al. 2009, Kloskowski et al. 2009, Legagneux et al. 2009), and makes it easier to count birds. During systematic counts performed in the agricultural fields surrounding the reservoirs (Sanchez-Guzmán et al. 2007, Masero et al. 2011) we also confirmed that dabbling ducks roosted in the reservoirs.

Ducks in reservoirs were counted simultaneously by different teams to avoid errors associated with potential bird movements between adjacent areas. We performed counts before (1991/1992, $1992 / 1993$ and $1993 / 1994$ winters) and after (2007/2008, 2008/2009 and 2009/2010 winters) the creation of those reservoirs close to the rice fields. Thus, during the first period we conducted surveys at the five large reservoirs (Orellana, Serena, Zújar, Alange and Canchales), as well as the Casas de Hitos pool (total area: 26,602 ha; Table 1; Fig. 1). During the second period, we additionally counted at the newly created reservoirs (Sierra Brava, Ruecas, Cubilar and Gargáligas; total area: 29,163 ha; Table 1). We scanned each area using binoculars and telescopes from selected vantage points. In the second period we used two boats to reduce the time spent covering the larger reservoirs.

Following Ramsar criteria, we specifically considered that a wetland should be considered internationally important if it regularly supports $1 \%$ of the population of one species, using the most recent population estimates (Delany and Scott 2006). To estimate wintering populations of each species we used the December and January counts (e.g. Navedo et al. 2007). We also considered the sum of all Anas spp. counted for analyses.

\section{Statistical analysis}

To examine whether wintering populations of dabbling ducks differed before and after the creation of several reservoirs near the rice fields, we used GLIMMIX procedure in SAS (SAS systems 2002) with Poisson error distribution and log-link function. Month and wintering season were included 
in the model as random factors, and period (before and after) was included as a two-level fixed factor. Accumulated precipitation ( $\mathrm{mm}$ ) in the study area (Sierra Brava) during the month of the count, as well as average air temperature in different parts of Europe and number of each species overwintering in Doñana during the month (see below) were considered as predictor variables.

Accumulated precipitation before each count was calculated as the sum of precipitation during the month of the count and the preceding months (e.g. December precipitation was calculated as the sum of October, November and December precipitation). We used the accumulated precipitation since we may expect an increase in individuals during dry periods (i.e. lower rainfall), when other natural wetlands located within the same geographical area at the flyway scale (e.g. Doñana area) overall received fewer numbers of dabbling ducks (Kloskowski et al. 2009). The monthly average air temperatures registered in different parts of Europe are of particular importance for overwintering dabbling ducks (Scott and Rose 1996) and were included to control for the potential effect of climatic conditions in other areas, since during cold spells southern European wetlands could receive individuals moving from northern areas (see Introduction). We considered data from Sierra Brava (study area), Doñana, Tablas de Daimiel, Ebro Delta, Camargue, Golfe du Morbihan, Bodensee, the Wash, Wadden Sea, Dee estuary and Nemunas Delta.

Numbers of each species counted during aerial surveys at Doñana were considered as another potential covariate, since both areas are very close at the flyway scale and any population change could be the result of redistribution of birds within nearby areas during the same season (Kloskowski et al. 2009, Guillemain et al. 2010). We calculated the difference between Extremadura and Doñana counts for each species (both log-transformed and extracted from Rendón et al. 2008, A. J. Green pers. comm.), as this variable should not be affected by common environmental factors but instead be related to the distribution of birds within both areas.

We examined the possibility of multicollinearity by considering Pearson correlation coefficients among covariates, as well as the variance inflation factor (VIF; PROC REG in SAS; SAS systems 2002) for each covariate in models. Predictors with VIF values exceeding to are generally used as indicators of significant multicollinearity (Graham 2003). Therefore, if the VIF of an independent variable was greater than 10 in the null models, this variable was dropped from the null model. VIFs and correlation coefficients of explanatory variables (accumulated precipitation and difference between Extremadura and Doñana counts (log-transformed) in all cases, while temperatures - Doñana, Sierra Brava, Dee estuary, Morbihan or Bodensee - varied according to species) incorporated into the null model were all $<5$ and $<0.6$, respectively. Model selection was carried out using Akaike's Information Criterion with small sample size correction (AICc; Burnham and Anderson 2002). The model with the lowest AICc value had the best support, but if the difference of AICc ( $\triangle \mathrm{AICc}$ ) between two models was less than two, they were considered to be equivalent (McCullagh and Nelder 1989).

Meteorological variables related to the study area were from the Agencia Estatal de Meteorología (Ministry of Environment) extracted from the official daily weather database in Spain. All temperatures used were downloaded from the CISL Research Data Archive (http://dss.ucar.edu/). We used a Mann-Whitney U-test to explore differences in the abundance of dabbling duck populations at the large old reservoirs between both periods. Data were transformed $[\log (x+1)]$ when necessary to satisfy assumptions of normality and homoscedasticity. Values presented are means \pm SE.

\section{Results}

An average of 25,277 \pm 4,810 individuals of genus Anas (range: 15,580-34,547) overwintered in the study area during $1992-1994$, increasing to $46,163 \pm 4,406$ (range: $37,264-66,779$ ) during 2007-2010. These later numbers included 7,235 $\pm 1,466$ Northern Pintail (range: 2,602-12,663), 8,187 $\pm 2,508$ Northern Shoveler (range: $1,041-16,573$ ), 9,389 \pm 942 Common Teal (range: 6,512-12,419), 18,270 $\pm 1,599$ Mallard (range: 13,410-23,632), 1,983 \pm 403 Gadwall (range: 967-3,836), and $1,099 \pm 275$ Eurasian Wigeon (range: 262-2,328). Apart from regularly meeting criterion 5 of the Ramsar Convention (i.e. support regularly more than 20,000 waterbirds), the area also meets criterion 6 (more than $1 \%$ of a distinct waterbird population) to be considered of 
international importance for Northern Shoveler and Mallard, as well as being close to the threshold for Northern Pintail, Common Teal and Gadwall (Table 2).

For the total wintering population, and for all species except Eurasian Wigeon, the best model included 'period'. This variable was therefore the most important factor in explaining the abundance of dabbling ducks in Extremadura. Northern Pintail, Northern Shoveler and Common Teal wintering populations increased significantly in the area during the second time period (Table 3, Figure 2). By contrast, wintering populations of Eurasian Wigeon underwent a decrease between the two periods (Figure 2). Local temperature was also included in an equivalent model accounting for differences in this species (Table 3). Mallard and Gadwall populations did not show any significant change (Table 3; Figure 2).

There were differences in population trends between reservoirs. Numbers of ducks at the large old reservoirs (Orellana, Zújar, and Serena) decreased overall (Figure 3) when the new reservoirs close to the rice fields were available during the second period. These decreases were significant for Northern Shoveler $(Z=2.87 ; P<0.01)$, Common Teal $(Z=3.03 ; P<0.01)$ and Eurasian Wigeon ( $Z=4.22 ; P<0.0001)$, when we pooled data from these old large reservoirs. The four new reservoirs (Sierra Brava, Gargáligas, Ruecas, and Cubilar) together held more than 35,00o wintering dabbling ducks during the latter period, representing c. $75 \%$ of the total individuals using the middle Guadiana basin. The irrigation pool located close to these four new reservoirs, as well the two other large reservoirs located far away, showed no significant changes (Casas de Hitos and Alange: $P=0.39$ in both cases) or even a slight increase (Canchales: $Z=-2.56 ; P<0.05$ ) in the number of wintering dabbling ducks (Figure 3). Furthermore, this multi-site wetland area consisting of the four new reservoirs near the rice fields supported the majority of the wintering populations of Northern Pintail, Northern Shoveler and Common Teal (Table 2).

\section{Discussion}

According to recent updates (Scott and Rose 1996, Martí and Del Moral 2003), the anthropogenic wetlands of Extremadura in the Guadiana basin currently hold more wintering Northern Pintail, Northern Shoveler and Common Teal populations than any other wetland in south-west Europe, apart from Doñana (Rendón et al. 2008). Thus, the area emerges as one of the most important

Table 2. Overwintering population size (means \pm SE) during both 1991-1994 and 2007-2010 periods, current international importance of the middle Guadiana basin and Vegas Altas area (VAG), and trends at flyway, regional and local level, for the guild of dabbling duck species (genus Anas). Trends: INC = Increasing; STA $=$ Stable; $\mathrm{DEC}=$ Decreasing.

\begin{tabular}{|c|c|c|c|c|c|c|c|c|}
\hline \multirow[b]{2}{*}{ Species } & \multicolumn{2}{|c|}{$\begin{array}{l}\text { Anas spp. } \\
\text { wintering in } \\
\text { middle } \\
\text { Guadiana } \\
\text { basin }\end{array}$} & \multicolumn{3}{|c|}{ Current Population } & \multicolumn{3}{|l|}{ Trends } \\
\hline & $\begin{array}{l}1991- \\
1994\end{array}$ & $\begin{array}{l}2007^{-} \\
2010\end{array}$ & $\begin{array}{l}\text { East Atlantic } \\
\text { Flyway }^{(1)}\end{array}$ & $\begin{array}{l}\text { Middle } \\
\text { Guadiana } \\
\text { basin (\%) }\end{array}$ & $\begin{array}{l}\text { Pop. } \\
\text { VAG (\%) }\end{array}$ & $\begin{array}{l}\text { East Atlantic } \\
\text { Flyway }^{(1)}\end{array}$ & Doñana ${ }^{(2)}$ & $\begin{array}{l}\text { Middle } \\
\text { Guadiana } \\
\text { basin }\end{array}$ \\
\hline A. acuta & 440 & 7,235 & 750,000 & 1.0 & 0.9 & DEC & STA & INC \\
\hline A. clypeata & 3,387 & 8,187 & 400,000 & 2.0 & 1.9 & STA & STA & INC \\
\hline A. crecca & 2,586 & 9,389 & $1,060,000$ & 0.9 & 0.8 & DEC & DEC & INC \\
\hline A. platyrhynchos & 10,347 & 18,270 & $1,000,000$ & 1.8 & 1.2 & INC & STA & STA \\
\hline A. strepera & 2,462 & 1,983 & 110,000 & 1.8 & 0.8 & STA & STA & STA \\
\hline A. penelope & 6,055 & 1,099 & 300,000 & 0.4 & 0.2 & DEC & DEC & DEC \\
\hline Anas spp. & 25,277 & 46,163 & & & & & & \\
\hline
\end{tabular}

${ }^{(1)}$ Delany and Scott 2006.

${ }^{(2)}$ Rendón et al. 2008. 
Table 3. Null and best models $(\triangle \mathrm{AICc}<2)$ of the GLIMMIX procedure evaluating the abundance (19911994 and 2007-2010 periods) of dabbling ducks (genus Anas) in the middle Guadiana basin in Extremadura. $\mathrm{T}$ local was the monthly mean temperature at Sierra Brava reservoir. $\left({ }^{*}\right)=P<0.05 ;\left({ }^{*}\right)=P<$ o.01; $\mathrm{ns}=$ non-significant

\begin{tabular}{|c|c|c|c|c|}
\hline Population & Models & $P$ & $\mathrm{AICc}$ & $\triangle \mathrm{AICc}$ \\
\hline \multirow[t]{2}{*}{ Anas spp. } & Period & \multirow[t]{2}{*}{$\left({ }^{*}\right)$} & -37.1 & o.o \\
\hline & Null model & & 18.2 & $55 \cdot 3$ \\
\hline \multirow[t]{2}{*}{ Anas acuta } & Period & \multirow[t]{2}{*}{$(* *)$} & -11.5 & 0.0 \\
\hline & Null model & & 17.0 & 28.5 \\
\hline \multirow[t]{2}{*}{ A. clypeata } & Period & \multirow[t]{2}{*}{$\left(^{*}\right)$} & -17.6 & 0.0 \\
\hline & Null model & & 20.2 & 37.8 \\
\hline \multirow[t]{2}{*}{ A. crecca } & Period & \multirow[t]{2}{*}{$\left(^{*}\right)$} & -16.0 & 0.0 \\
\hline & Null model & & 22.1 & 38.1 \\
\hline \multirow[t]{2}{*}{ A. platyrhynchos } & Period & \multirow[t]{2}{*}{ ns } & -22.7 & 0.0 \\
\hline & Null model & & 16.8 & $39 \cdot 5$ \\
\hline \multirow[t]{2}{*}{ A. strepera } & Period & \multirow[t]{2}{*}{ ns } & -15.3 & 0.0 \\
\hline & Null model & & 21.3 & 36.6 \\
\hline \multirow[t]{3}{*}{ A. Penelope } & Period & $(*)$ & -15.0 & 0.0 \\
\hline & Period $+\mathrm{T}$ Local & \multirow[t]{2}{*}{$\left({ }^{*}\right)$} & -15.5 & 0.5 \\
\hline & Null model & & 21.2 & 36.2 \\
\hline
\end{tabular}

wintering sites for dabbling ducks in southern Europe, with the majority of birds inhabiting the four new reservoirs created close to the rice fields (the so-called Vegas Altas area).

With the exception of Eurasian Wigeon and Gadwall, wintering dabbling duck populations in Extremadura are currently higher than those recorded 15 years ago. Although our results were derived from three winter seasons during each period, they reflect the medium-term trends in the study area. As an example, the maximum figures for Mallard and Common Teal populations during 1991-2001 at Orellana reservoir, which was the most important site for waterbirds in the area (Martí and Del Moral 2003), were less than half the mean numbers for both species found during this study. Moreover they also reflect the overall decline recorded for Eurasian Wigeon populations (Rendón et al. 2008). When controlling for other environmental and seasonal

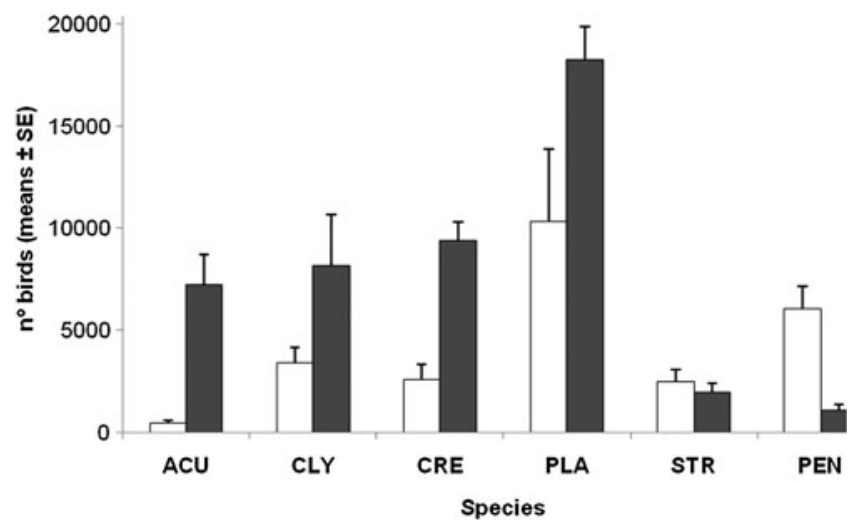

Figure 2. Number of each species of dabbling duck wintering at the studied reservoirs within the middle Guadiana basin (SW Spain) before (open bars) and after (solid bars) the creation of several small ones between the old large dams and the rice fields. ACU = Anas acuta; CLY = Anas clypeata; $\mathrm{CRE}=$ Anas crecca $; \mathrm{PLA}=$ Anas platyrhynchos; $\mathrm{STR}=$ Anas strepera $;$ and $\mathrm{PEN}=$ Anas penelope. 


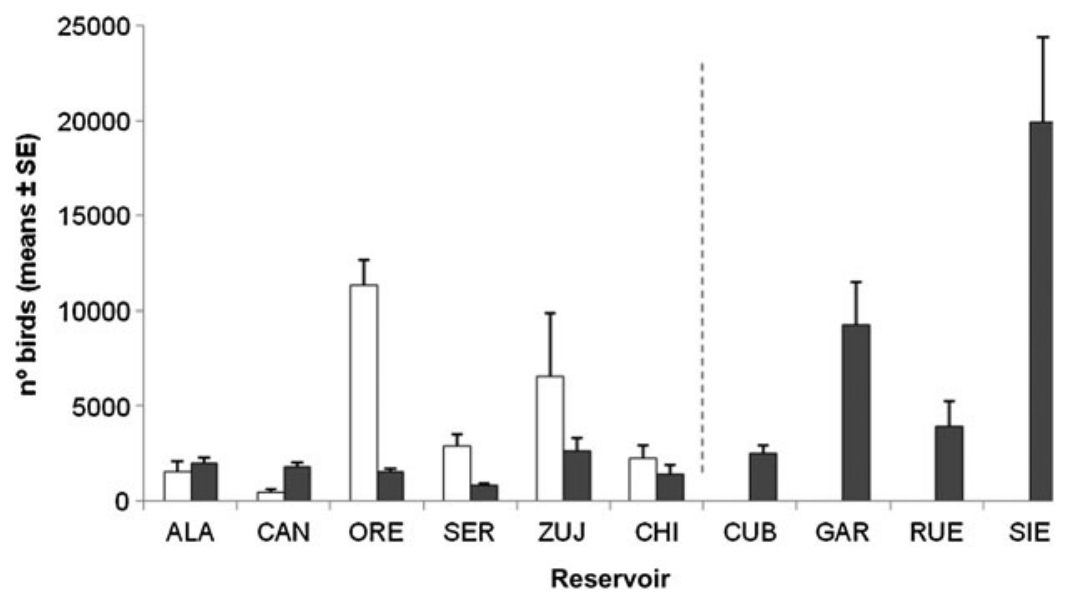

Figure 3. Number of dabbling ducks (Anas spp. all species combined; see text for details) wintering at each of the reservoirs studied within the middle Guadiana basin (SW Spain) before (open bars) and after (solid bars) the creation of several small ones (right to the pointed line) between the old large dams (left to the pointed line) and the rice fields. ALA = Alange; CAN = Canchales; ORE = Orellana; SER = Serena; ZUJ = Zújar; $\mathrm{CHI}=$ Casas de Hitos; $\mathrm{CUB}=$ Cubilar; GAR $=$ Gargáligas; $\mathrm{RUE}=$ Ruecas; and SIE $=$ Sierra Brava.

variables, wintering populations of Northern Pintail, Northern Shoveler and Common Teal increased between both periods. These increases were neither affected by population trends at the biogeographical scale, nor reflect movements due to cold spells (Ridgill and Fox 1990) as populations were stable for Northern Shoveler and decreasing for the other two (Delany and Scott 2006) and the temperature registered in different parts of Europe had hardly any effect on the abundance of these species in the study area.

As long-distance migrants breeding in northern Europe and Russia (Scott and Rose 1996), Northern Pintail, Northern Shoveler and Common Teal may benefit from migrating over shorter distances and exploiting the new artificial habitats available within the EAF, as observed for conspecifics in Central Europe (Svazas et al. 2001). Northern Pintails probably did not come from other important nearby areas in south-west Europe, such as Doñana, as its long-term population was stable (Rendón et al. 2008). Nevertheless, the overall decline registered in the western Sahel, from 600,000 to 400,000 individuals between 1980 and 2006 (Zwarts et al. 2008), could be the result of a partial redistribution of birds in south-west Europe, including Extremadura. However, the redistribution of Common Teal could be the result of a partial shift by birds coming from other areas in south-west Europe, the southern limit of the distribution of the species (Scott and Rose 1996), where their populations have shown a marked long-term decrease, as at Doñana (Rendón et al. 2008) or Tablas de Daimiel (authors' pers. obs.). The increase in Northern Shoveler should also partially reflect a similar redistribution of birds in south-west Europe. For example, this species experienced an overall reduction in its wintering abundance from the mid-199os onwards in Doñana, despite its stable trend in the long-term (1978-2005) (Rendón et al. 2008). Other changes associated with environmental conditions, such as different availability of foraging resources between inland and coastal rice fields, could also affect numbers wintering in the study area, in particular for Common Teal, due to the high turnover within wintering populations (Pradel et al. 1997, Guillemain et al. 2010). Therefore the increase in wintering populations of these species in the study area reflects an improvement in functional and geographically linked systems (Tamisier 1985) between both periods. These improvements were driven by the creation of the new reservoirs functioning as roosting sites near extensive rice fields used as foraging areas. 
By contrast, the general decline of Eurasian Wigeon populations within the EAF (Delany and Scott 2006) could have driven the declines observed in the study area. We discarded a possible redistribution at a regional level, as the reservoirs studied held a mean of $81.6 \%$ of the wigeon wintering within the 45 wetlands of the whole middle Guadiana basin during the 2007/2008, 2008/ 2009 and 2009/2010 seasons (J.M. Sánchez-Guzmán unpubl. data). The creation of the small reservoirs would not reflect a habitat improvement for this species as it forages during daylight by grazing in flocks along the shores of these areas, rather than commuting between roosting and foraging grounds (Campredon 1981).Wintering populations of Mallard increased, but changes cannot be associated with an improvement in habitat conditions as abundances were not significantly different between the two periods. The higher behavioural plasticity of this species compared to conspecifics (Del Hoyo et al. 1992, Scott and Rose 1996, Kear 2005), leads to it commonly using other wetland habitats such as rivers, temporary wetlands or small ponds, and this factor could also have partially affected our results. Finally, the Gadwall population did not change between periods, probably reflecting the different ecological requirements of this species which forages during daylight (Paulus 1984), as well as its different phenology in the area (Amat 1982).

\section{Conservation implications}

This study extends the findings of Sánchez-Guzmán et al. (2007), who suggested that the creation of rice fields in the middle Guadiana basin may have modified the wintering sites of some waterbird species using the EAF. Since they studied the use of rice fields during daylight, they missed the importance of these areas as nocturnal foraging grounds (McNeil et al. 1992). Although we cannot demonstrate it, the creation of these small reservoirs could have driven a partial redistribution of wintering dabbling ducks in the EAF, probably switching from natural marshes in south-west Europe or even Sahelian wetlands to artificial habitats in Extremadura. Our results suggest that the existence, close to foraging areas, of reservoirs with specific characteristics that can be used as daylight roost sites, has increased the availability of suitable habitat for dabbling ducks (Tamisier 1985), particularly for species that commute between roosting and feeding grounds. It should also lead to a major energy saving for wintering dabbling ducks by reducing daily flight distances, as found for wintering Common Crane Grus grus in the area (Sánchez et al. 1999).

Although many small reservoirs have been built in the upper parts of the tributaries of the Guadiana river in Extremadura, we do not advocate the transformation of natural wetland areas into reservoirs. Apart from their potential consequences on aquatic fauna and flora (Finlayson et al. 1992), in particular plants and invertebrates (e.g. Green et al. 2002), waterbirds that rely on vegetated wetlands and require reeds for nesting were also predisposed to range contraction due to habitat loss (Okes et al. 2008). Furthermore, whether the wintering use of this inland habitat will drive a long-term population benefit for dabbling ducks remains an unsolved question which merits further investigation.

In any case, to guarantee that protected sites are adequate and adapted as needed over a large geographical area (Boere and Taylor 2004) and in a context of wetland connectivity (Haig et al. 1998), this artificial multi-site wetland area composed of the four new small reservoirs and associated rice fields needs protection by legal mechanisms (extending the current ESoooo333 SPA area) since it represents a key site in the EAF under Ramsar criteria 5 and 6 for the conservation of dabbling ducks, some of them showing long-term decreasing trends (Delany and Scott 2006). Considering the large number of solar energy plants and wind farms being proposed for this area (Cardalliaguet 2008), protection would greatly reduce the expansion of infrastructure in the surrounding rice fields (Masero et al. 2011). As proposed by Sánchez-Guzmán et al. (2007) the management of these sites (artificial flooding of rice fields in dry winters using water from adjacent reservoirs, hunting and sport fishing regulation, path creation) would guarantee the existence of a large functional wetland area which can play an important role in mitigating the loss of natural wetlands for populations of different waterbirds using the EAF. Finally as a previously unused area that has not been taken into account in the compilation of the International Waterfowl Census, the mean wintering population of 
each species recorded in this study should be added to the overall current estimates (Delany and Scott 2006) to obtain updated figures of different population sizes and trends.

\section{Acknowledgements}

We are very grateful to Arturo López, Francisco J. Medina, Pedro Corbacho, Eduardo da Silva, Domingo Rivera, Isabel T. Escribano, Carlos Rangel, Francisco Capote, Gema Lagoa, Mamen Molina, Francisco Santiago-Quesada, Noelia Albano, Bettina Perales and Elsa Martín for field assistance. Dr. Martin Schneider-Jacoby, Dr. Guillermo Fernández, Dr. Alfredo Castillo-Guerrero, Dr. Andy J. Green and an anonymous reviewer made invaluable comments on an earlier draft. Óscar Uceda helped with graphics. Agencia Española de Meteorología-AEMet supplied meteorological data for the study area. Censuses were financially supported by PRIogC128 (Junta de Extremadura) and Confederación Hidrográfica del Guadiana (belonging to the Spanish Ministry of the Environment) thanks to different agreements signed with University of Extremadura. JGN was supported by a postdoctoral fellowship of Plan Regional de Investigación (III PRI+D+I) of Junta de Extremadura.

\section{References}

Amat, J. A. (1982) The nesting biology of ducks in the Marismas of the Guadalquivir, south-western Spain. Wildfowl 33: 94-104.

Boere, G. C. and Taylor, D. (2004) Global and regional governmental policy and treaties as tools towards the mitigation of the effect of climate change on waterbirds. Ibis 146: 111-119.

Brochet, A-L., Gauthier-Clerc, M., Mathevet, R., Béchet, A., Mondain-Monval, J-Y. and Tamisier, A. (2009) Marsh management, reserve creation, hunting periods and carrying capacity for wintering ducks and coots. Biodivers. Conserv. 18: 1879-1894.

Burnham, K. P. and Anderson, D. R. (2002) Model selection and multimodel inference: a practical information theoretic approach. $2^{\text {nd }}$ edition. New York: Springer.

Camphuysen, C. J., Ens, B. J., Heg, D., Hulscher, J. B., Vandermeer, J. and Smit, C. J. (1996) Oystercatcher Haematopus ostralegus winter mortality in The Netherlands: the effect of severe weather and food supply. Ardea 84: 469-492.

Campredon, P. (1981) Hivernage du canard siffleur (Anas penelope) L. en Camargue (France), stationnements et activities. Alauda 49: 161-193.

Cardalliaguet, M. (2008) Nueva avalancha de proyectos eólicos en Extremadura. La Garcilla 135: 36.

Cox, R. R. and Afton, A. D. (1996) Evening flights of female Northern Pintails from a major roost site. Condor 98: 810-819.
Del Hoyo, J., Elliot, A. and Sargatal, J., eds. (1992) Handbook of the birds of the world. Vol. 1. Ostrich to ducks. Barcelona, Spain: Lynx Edicions.

Delany, S. and Scott, D. A. (2006) Waterbird population estimates - $4^{\text {th }}$ edition. Wageningen, The Netherlands: Wetlands International.

Dugan, P. J. (1990) Wetland conservation. A review of current issues and required action. Gland, Switzerland: IUCN.

Elphick, C. S. (2000) Functional equivalency between rice fields and seminatural wetland habitats. Conserv. Biol. 14: 181-191.

Felicísimo, A. M., Morán, R., Sánchez, J. M. and Pérez, D. (2001) Elaboración del atlas climático de Extremadura mediante un sistema de información geográfica. GeoFocus 1: 17-23.

Finlayson, C. M., Hollis, G. E. and Davis, T., eds. (1992) Managing Mediterranean wetlands and their birds. Proceedings of an IWRB International Symposium, Grado, Italy, February 1991. Slimbridge, UK: IWRB. (IWRB Special Publication No. 20).

Fox, A. D. and Madsen, J. (1997) Behavioural and distributional effects of hunting disturbance on waterbirds in Europe: implications for refuge design. J. Appl. Ecol. 34: 1-13.

García, L. (1994) Los ríos extremeños. Badajoz, Spain: Servicio de Publicaciones de la Universidad de Extremadura.

Graham, M. H. (2003) Confronting multicollinearity in ecological multiple regression. Ecology 84: 2809-2815. 
Green, A. J., El Hamzaoui, M., El Agbani, M. A. and Franchimont, J. (2002) The conservation status of Moroccan wetlands with particular reference to waterbirds and to changes since 1978. Biol. Conserv. 104: 71-82.

Guillemain, M., Fritz, H. and Duncan, P. (2002) The importance of protected areas as nocturnal feeding grounds for dabbling ducks wintering in western France. Biol. Conserv. 103: 183-198.

Guillemain, M., Mondain-Monval, J-Y., Johnson, A. R. and Simon, G. (2005) Longterm climatic trend and body size variation in teal Anas crecca. Wildl. Biol. 11: 81-88.

Guillemain, M., Devineau, O., Brochet, A. L., Fuster, J., Fritz, H., Green, A. and GauthierClerc, M. (2010) What is the spatial unit for a wintering teal Anas crecca? Weekly day roost fidelity inferred from nasal saddles in the Camargue, southern France. Wildl. Biol. 16: 215-220.

Haig, S. M., Mehlan, D. W. and Oring, L. W. (1998) Avian movements and wetland connectivity in landscape conservation. Conserv. Biol. 12: 749-758.

Hulscher, J. B., Exo, K-M. and Clark, N. A. (1996) Why do Oystercatchers migrate? Pp. $155-185$ in J. D. Goss-Custard, ed. The Oystercatcher: from individual to populations. Oxford, UK: Oxford University Press.

Kear, J. (2005) Ducks, geese and swans. Oxford, UK: Oxford University Press.

Kloskowski, J., Green, A. J., Polak, M., Bustamante, J. and Krogulec, J. (2009) Complementary use of natural and artificial wetlands by waterbirds wintering in Doñana, south-west Spain. Aquatic Conserv: Mar. Freshw. Ecosyst. 19: 815-826.

Legagneux, P., Blaize, C., Latraube, F., Gautier, J. and Bretagnolle, V. (2009) Variation in home-range size and movements of wintering dabbling ducks. J. Ornithol. 150: 183-193.

Martí, R. and Del Moral, J. C. (2003). La invernada de aves acuáticas en España. Madrid, Spain: Ministerio de Medio Ambiente. Dirección General de Conservación de la Naturaleza-SEO/BirdLife.

Masero, J. A. (2003) Assessing alternative anthropogenic habitats for conserving waterbirds: salinas as buffer areas against the impact of natural habitat loss for shorebirds. Biodivers. Conserv. 12: 1157-1173.

Masero, J. A., Santiago-Quesada, F., SánchezGuzmán, J. M., Villegas, A., Abad-Gómez, J. M., Lopes, R., Encarnaçao, V. Corbacho, C. and Morán, R. (2011) Long lengths of stay, large numbers, and trends of the Black-tailed Godwit Limosa limosa in rice fields during spring migration. Bird Conserv Internatn. 21: 12-24.

McCullagh, P. and Nelder, J. A. (1989) Generalized linear models. $2^{\text {nd }}$ ed. Boca Raton, Florida: Chapman \& Hall/CRC.

McNeil, R., Drapeau, P. and Goss-Custard, J. D. (1992) The occurrence and adaptive significance of nocturnal habits in waterfowl. Biol. Rev. 67: 381-419.

Morrison, R. I. G., Aubry, Y., Butler, R. W., Beyersbergen, G. W., Downes, C., Donaldson, G. M., Gratto-Trevor, C. L., Hicklin, P. W., Johnston, V. H. and Ross, R. K. (2001) Declines in North American shorebird populations. Wader Study Group Bull. 94: $34-38$.

Moureau, R. E. (1972) The Palaearctic-African bird migration systems. London, UK: Academic Press.

Navedo, J. G., Masero, J. A. and Juanes, J. A. (2007) Updating waterbird population estimates within the East Atlantic Flyway: status and trends of migratory waterbirds in Santoña marshes. Ardeola 54: 237-249.

Nilsson, C., Reidy, C. A., Dynesius, M. and Revenga, C. (2005) Fragmentation and flow regulation of the world's large river systems. Science 308: 405-408.

Okes, N. C, Hockey, P. A. R. and Cumming, G. S. (2008) Habitat use and life history as predictors of bird responses to habitat change. Conserv. Biol. 22: 151-162.

Pandey, S. (1993) Changes in waterbird diversity due to the construction of Pong dam reservoir, Himachal Pradesh, India. Biol. Conserv. 66: 125-130.

Paulus, S. L. (1984) Activity budgets of nonbreeding gadwalls in Louisiana. J. Wildl. Manage. 48: 371-380.

Pradel, R., Rioux, N., Tamisier, A. and Lebreton, J. D. (1997) Individual turnover among wintering teal in Camargue: a mark-recapture study. J. Wildl. Manage. 61: 816-821. 
Rendón, M. A., Green, A. J., Aguilera, E. and Almaraz, P. (2008) Status, distribution and long term changes in the waterbird community wintering in Doñana, south-west Spain. Biol. Conserv. 141: 1371-1388.

Ridgill, S. C. and Fox, A. D. (1990) Cold weather movements of waterfowl in Western Europe. Slimbridge, UK: IWRB. (IWRB Special Publication No. 13).

Sánchez, J. M., Sánchez, A., Fernández, A. and Muñoz del Viejo, A. (1993) La Grulla común (Grus grus) en Extremadura. Status y relación con el uso del suelo. Badajoz, Spain: Junta de Extremadura and G.I.C.

Sánchez, J. M., Sánchez, A., Corbacho, C. and Muñoz del Viejo, A. (1999). Influence of farming activities in the Iberian Peninsula on the winter habitat use of common crane (Grus grus) in areas of its traditional migratory routes. Agric. Ecosyst. Environ. 72: 207-214.

Sánchez-Guzmán, J. M., Morán, R., Masero, J. A., Corbacho, C., Costillo, E., Villegas, A. and Santiago-Quesada, F. (2007) Identifying new buffer areas for conserving waterbirds in the Mediterranean basin: the importance of the rice fields in Extremadura, Spain. Biodivers. Conserv. 16: 3333-3344.

SAS systems (2002) Statistical Analysis Software. www.sas.com

Scott, D. A. and Rose, P. M. (1996) Atlas of Anatidae populations in Africa and West- ern Eurasia. Wageningen, The Netherlands: Wetlands International. (Wetlands International Publication $\mathrm{n}^{\circ}$ 4I).

Svazas, S., Meissner, W., Serebryakov, V., Kozulin, A. and Grishanov, G. (2001) Changes of wintering sites of waterfowl in central and eastern Europe. Vilnius, Lithuania: OMPO Special Publication.

Tamisier, A. (1985) Some considerations on the social requirements of ducks in winter. Wildfowl 36: 104-108.

Toral, G. M. and Figuerola, J. (2010) Unraveling the importance of rice fields for waterbird populations in Europe. Biodivers. Conserv. 19: 3459-3469.

Weller, M. W. (1988) Waterfowl in winter. Minneapolis: University of Minnesota Press.

Yasué, M. and Dearden, P. (2009) The importance of supratidal habitats for wintering shorebirds and the potential impacts of shrimp aquaculture. Environ. Manage. 43: 1108-1111.

Zamora, J. F. (1987) El río Guadiana. Fisiografía, geoquímica y contaminación. Badajoz, Spain: Departamento de Publicaciones de la Excma. Diputación de Badajoz.

Zwarts, L., Bijlsma, R. B., Van der Kamp, J. and Wymenga, E. (2008) Living on the edge: wetlands and birds in a changing Sahel. Zeist, The Netherlands: KNNV Publishing.

JUAN G. NAVEDO ${ }^{\dagger *}$, JOSÉ A. MASERO, JUAN M. SÁNCHEZ-GUZMÁN, JOSÉ M. ABAD-GÓMEZ, JORGE S. GUTIÉRREZ, ESTHER G. SANSÓN, AUXILIADORA VILLEGAS, EMILIO COSTILLO, CASIMIRO CORBACHO, RICARDO MORÁN

Conservation Biology Research Group, Zoology, University of Extremadura, Avenida de Elvas s/n, 06071 Badajoz, Spain.

${ }^{\dagger}$ Current address: Unidad Académica Mazatlán, Instituto de Ciencias del Mar y Limnología, Universidad Nacional Autónoma de México, Apartado Postal 811, Mazatlán, Sinaloa, México.

*Author for correspondence; e-mail: jgnavedo@unex.es

Received 28 January 2011; revision accepted 3 June 2011; Published online 5 December 2011 